\title{
Implications of Regulatory Drought for farmer Use of Climate Information in the Klamath Basin
}

\author{
KRISTIN VANDERMOLEN \\ Division of Atmospheric Sciences, Desert Research Institute, Reno, Nevada \\ AlEXANDRA HORANGIC \\ Institute for the Environment, The University of Arizona, Tucson, Arizona
}

(Manuscript received 24 July 2017, in final form 8 January 2018)

\begin{abstract}
Despite the risk of climate variability to agriculture, farmer use of climate information in agricultural decision-making generally remains low. Research has suggested that where farmers already have robust "repertoires" of decision-making resources adapted to some degree of climate variability, such new information may simply factor less saliently. This study asks whether farmer use of climate information increases under the occurrence of more extreme climatic events for which those repertoires lack referent-in this case, severe hydrological and related regulatory drought in the Klamath basin. Semistructured interviews with key informants of Klamath basin agriculture indicate a marked increase in farmer use of climate and climate-related information since the onset of drought in 2001. What information farmers utilize, however, depends on whether it retains its predictive and explanatory value under both types of drought. Findings highlight the need for consideration of coproduction approaches to the development of climate information if it is to serve farmers where the extremity of climate events produces changes not only in availability of but also in access to key agricultural resources.
\end{abstract}

\section{Introduction}

Climate variability represents a major risk to agriculture for its potential to influence a host of production factors, like water availability, pest or disease outbreak, and commodity prices (Fraisse et al. 2006). Yet farmer consideration of climate information-such as seasonal precipitation and drought outlooks-in agricultural decision-making remains low (Haigh et al. 2015b). One reason noted for this is that climate information represents only one of many resources farmers may leverage within "dynamic repertoire[s] of knowledge, skills, networks, and technologies contextualized in immediate social and biophysical conditions" in making decisions (Crane et al. 2010, p. 46). This suggests not only that new information must integrate into existing repertoires as "one element among many" (Crane et al. 2010, p. 46), but also that where these are sufficiently robust to enable adaptation to some degree of climate variability,

\footnotetext{
Corresponding author: Kristin VanderMolen, kristin.vandermolen@ dri.edu
}

new information may simply factor less prominently (Meinke and Stone 2005).

We therefore ask whether climate information becomes more salient within farmer decision-making under the occurrence of extreme climatic events, that is, when conditions change beyond the adaptive scope of established repertoires. Siting the research within the Klamath basin, an area that has experienced frequent and severe drought since 2001, we found that climate information use has increased though selectively as farmers consider much of it to lose its predictive and explanatory value under the ensuing regulation of water resources. We therefore suggest that farmer climate information use may increase under the more extreme climatic events predicted for much of the western United States in the future (Dalton et al. 2013; Gershunov et al. 2013) but caution that if this information is to serve farmers under related changes in both biophysical and social (or in this case sociopolitical) conditions, consideration should be given for its coproduction.

The negative consequences to agriculture of the 1998 El Niño prompted researchers to explore the potential 
for climate information to aid agricultural decisionmaking (Crane et al. 2010). In so doing, they found that when spatial and temporal scales are appropriate (Cabrera et al. 2007; Hollinger 2009), climate information may be of use to farmers, most notably in strategic decisions made prior to the growing season intended to capitalize favorable or mitigate unfavorable conditions (Breuer et al. 2008; Phillips et al. 2002). Such decisions include those related directly to production, such as crop and varietal selection (Roudier et al. 2014), timing of planting (Jagtap et al. 2002), and application of inputs (Asseng et al. 2012), as well as those related to broader operational factors, such as adopting new irrigation and greenhouse infrastructure and committing to labor and marketing contracts (Furman et al. 2011).

Research also has found, however, that beyond appropriateness of scale, the potential for farmers to benefit from climate information additionally depends on overcoming any number of barriers to use. These include, among others (Mase and Prokopy 2014), forecast skill (Ash et al. 2007); adequate lead time (Klopper et al. 2006); social norms (Artikov et al. 2006); livelihood goals (Crane et al. 2010); comprehensibility, trustworthiness, and quantity of information (Crane et al. 2008b; Haigh et al. 2015a; McCrea et al. 2005); flexibility in farm management (Cabrera et al. 2006); and farmer perceptions of and strategies for managing risk (Crane et al. 2008a). As researchers have made efforts to elucidate and overcome these barriers, they have moved increasingly from a science-driven to a stakeholderdriven or coproduction approach (Bartels et al. 2013; Prokopy et al. 2017). When coproduced, farmers participate in defining research agendas and in developing and testing climate information to increase the likelihood of beneficial use (Breuer et al. 2009). Yet, as in the Klamath basin, it remains that much of the climate information available to farmers has not been produced with their input.

Following, we introduce the study area and methods. We then present research findings related to farmer experience with drought and perceptions and use of climate information. In concluding, we suggest that it will become increasingly important for researchers to consider coproduction approaches to the development of climate information under changes in both biophysical and sociopolitical conditions.

\section{Study area}

The Klamath basin offers a suitable site for exploring farmer use of climate information under extreme climatic events for the frequency of drought and the severity of its consequences to agriculture. Most farming in the basin takes place north of the California-Oregon border in the areas surrounding Upper Klamath Lake (UKL) (Fig. 1). UKL is the main storage area of the Klamath Project (or simply Project hereinafter), a 1905 reclamation project designed to irrigate more than 200000 acres annually. Its main stem is the Klamath River, impounded by multiple hydroelectric dams that generate power and regulate flows. Each year the Bureau of Reclamation creates a management plan for the Project that determines allocations of water for agriculture based on water year type (above average, below average, dry, or critically dry) and in accordance with established water rights and the dictates of the Biological Opinions (see, e.g., National Marine Fisheries Service and U.S. Fish and Wildlife Service 2013) for three endangered fish species that inhabit UKL and the Klamath River. In short, each year the Bureau must balance water for agriculture with priority demands, these being the minimum lake-level and streamflow requirements for maintaining adequate fish habitat (Doremus and Tarlock 2008).

In 2001, unprecedented drought left not enough water to implement the Biological Opinions, intensifying long-held tensions over the balance of Project water resources and prompting the Bureau to curtail all water to UKL irrigators (Doremus and Tarlock 2008). Since then, the basin has continued to experience frequent hydrological and related regulatory drought and, with it, conflict among stakeholder groups with different interests in water related to agriculture, environmental protection, and hydroelectric development. Over the last 16 years as these groups have engaged in litigation and attempts at comprehensive agreements in efforts to secure water for their particular interests, allocations and the potential for curtailment have come to vary not only by water year type, but also by ongoing changes in the Biological Opinions, water rights, and management (Horangic et al. 2016; Powers et al. 2005).

All stakeholders-agricultural, environmental, and hydroelectric - are vulnerable to drought in the basin. Here, however, we focus on the use of climate information among grass, grain, and row crop farmers located below UKL who rely on its waters to irrigatenoting, importantly, that this may differ from "offproject" farmers in the basin who lack access to the same. ${ }^{1}$ For UKL irrigators, regulatory drought may take the form of reduced allocation at the beginning or curtailment of that allocation during the growing season, or

\footnotetext{
${ }^{1}$ Commonly referred to as "off-project," there are farms within the Klamath basin that do not receive water from the Klamath Project (Doremus and Tarlock 2008). As such, it is important to note that their use of and needs for climate information may differ from those of UKL irrigators.
} 


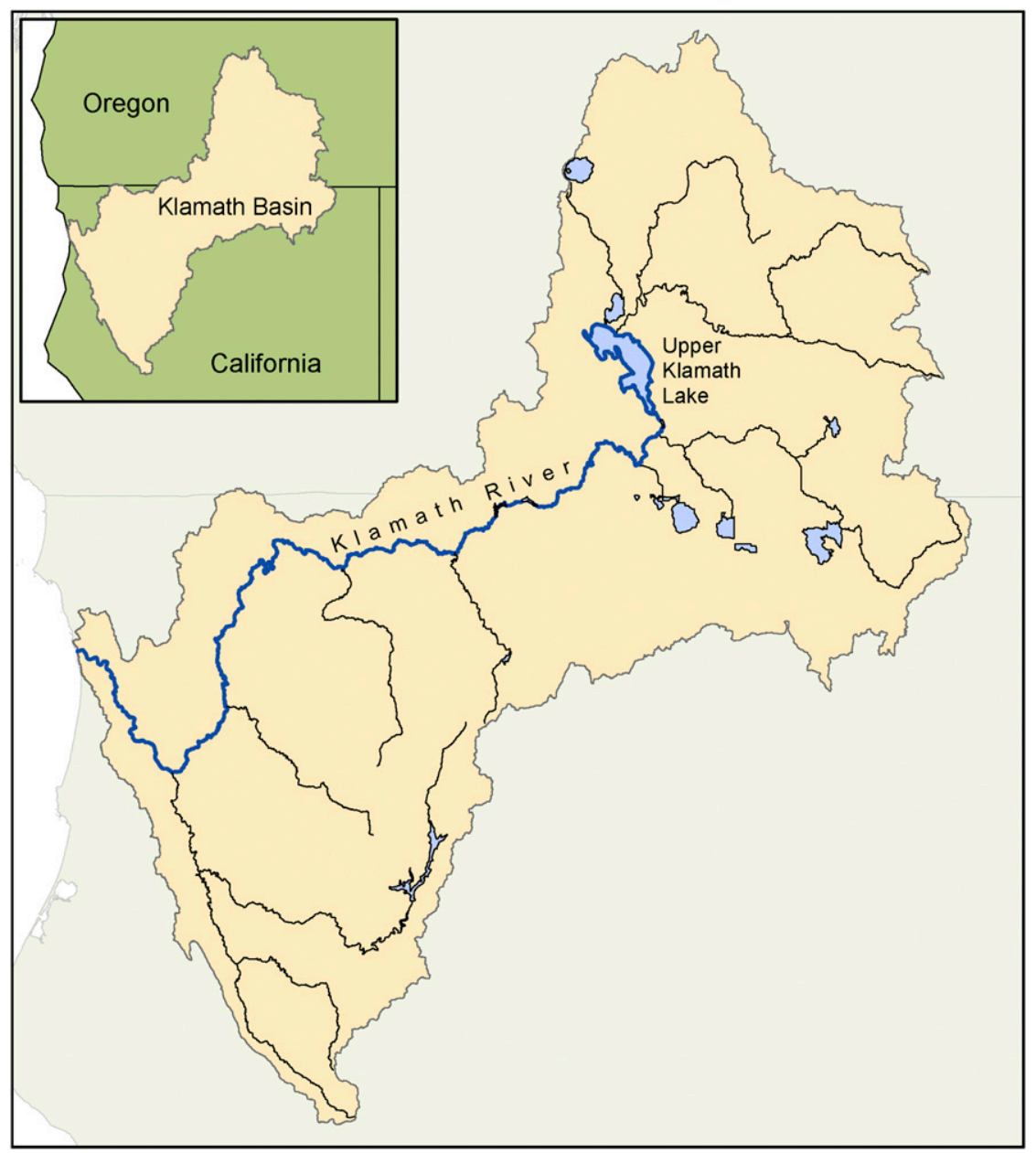

FIG. 1. Map of Klamath basin.

both, depending on the amount of water available and whether priority demands remain met under any changes in inflows and management.

\section{Methods}

To explore whether climate information has become more salient in farmer decision-making under the occurrence of severe drought, we employed a rapid assessment (Bernard 2006) of the resources farmers draw on to adapt. The assessment consisted of 13 semistructured interviews with key informants of the signaled farming group between November and December of 2016. Informants (with numbers of each in parentheses) included an extension officer (1), representatives of local irrigation districts and agricultural organizations (2), relevant federal and state agency representatives (3), an agricultural consultant (1), and farmers (6) identified through a scoping interview with the former.
Such purposive sampling is common in social science research with farmers (Bernard 2006) and reflects our intention to provide insight into emergent opportunities and constraints for climate information use in agriculture rather than to generalize about all farming in the basin.

Interviews inquired into farm demographics, agricultural context, decision-making strategies related to drought, and experience with and perceptions of climate information. The latter included or related to seasonal climate, precipitation and drought outlooks, water resource availability, and crop and soil moisture, none of it coproduced. Using a grounded-theory approach (Bernard 2006), we created summaries of responses for individual questions from interview recordings and detailed notes and used those summaries to identify relevant analytic categories (e.g., experience with drought). We then reviewed the data within each category to identify patterned themes (e.g., drought as primary 
concern for agriculture). Here we present data from two of those categories-experience with drought and climate information use-to convey both the context and reasoning for how and why farmers use that information to adapt.

\section{Research findings}

\section{a. Experience with drought}

Despite long-held tensions over the balance of Project water resources, drought was not of great concern to farmers until 2001. Since then, drought has been the biggest challenge to agriculture, with interviewees emphasizing that after nearly two decades of conflict and related changes in Biological Opinions, water rights, and management, many consider sociopolitics rather than climate to be its stronger indicator. One farmer explains:

The definition of a drought is changing every year. From an agricultural standpoint, based off of Biological Opinions and lawsuits, you can have a water year that's technically 100 percent of what you should get and we might end up with a [minimal] delivery. In a year where we might have 70 percent of a full water year, that might actually be a year that we end up with a full water delivery. So it's actually the politics of water that we pay more attention to than whether they're calling it a drought.

Often farmers are able to maintain relatively steady production during years of hydrological drought, but for its severity and variability, outcomes of regulatory drought have been marked, including significant crop and revenue loss and early release of laborers (Powers et al. 2005). Part of the difficulty in adapting to regulatory drought is in the timing of allocation and curtailment. Generally, allocation takes place in April, months after farmers have planned for the season, and curtailment during summer, well after production is underway. Both put farmers at risk.

Under regulatory drought, farmers typically prioritize the protection of perennials, in general, and annuals grown on contract, though not without effect. For example, often farmers will reduce the number of cuttings of perennials, with one agricultural consultant noting that "if a farmer's budget, capital repayment, and mortgage is predicated on at least three cuttings, it [curtailment] is obviously not without impact." A farmer explains of annuals, "if you're growing potatoes on contract, those people are making commitments to those supplies today [December], and if you become an unreliable supplier, they go someplace else." Farmers also let some crops go, primarily those not grown on contract, as one farmer explains, albeit to the detriment of supporting industries: "For example, grain storage facilities, they've taken a real pounding in the lean years because that's where the flux in water consumption would take place, by people that are protecting their market share of other contracted commodities."

Already the Klamath Project recycles tailwater and operational spill. Further, since 2001, most farmers interviewed have experimented with one or more drought adaptation strategy, including transitioning from flood irrigation to sprinklers, laser-leveling fields, monitoring irrigation rates, using drought-tolerant crops, participating in land idling programs, attending informational meetings on water use and availability, and using climate and climate-related information in an effort to anticipate allocation and curtailment.

\section{b. Climate information use}

All interviewees agreed that, since 2001, farmer use of climate and climate-related information has increased in the form of attention to snowpack, streamflow, and lake-level monitoring and forecast via U.S. Geological Survey and Natural Resource Conservation Service websites. One farmer explains, "In our neighborhood, now everybody is looking at SNOTEL sites. We know where the watershed is, we know where snow piles up, we know what the trends are and have historically been." During winter and early spring, farmers use this information in conjunction with attention to local sociopolitics in an effort to gauge allocations and make cropping, contracting, fallowing, and other planning decisions accordingly. During late spring and summer, farmers use the same combination of information to anticipate any changes in inflows and legal action that might foreshadow curtailment. One consultant summarized, "Mostly in early spring we have a good idea [of the water available], but with adjudication, Biological Opinions, and court and judicial action, the target moves a lot."

With one exception, interviewees reported not using any additional climate information, although most offered several ideas for how it could be applied where drought is only hydrological; for example, noting the use of drought outlooks in preseason planning. In their own context, however, where drought is both hydrological and regulatory, a district water manager explains about climate information that "we'd be interested but everything is done through the Biological Opinions and we're contractors with the Bureau of Reclamation, so in essence the Klamath Project gets the allotment from the Bureau of Reclamation and then we manage with whatever that is." In short, for these farmers, beyond those resources that inform directly about current and projected water availability, additional information like 
seasonal climate and drought outlooks may provide indication of variation in climate, but not that they can readily operationalize under the related uncertainty of variation in water rights and management.

\section{Summary}

Since 2001, drought in the Klamath basin has produced marked changes both in biophysical and in sociopolitical conditions, resulting in several years of reduced water availability for agriculture. As farmers have experienced crop and revenue loss as a result of these changes, they have experimented with multiple adaptation strategies, including attention to climate and climate-related information in the form of snowpack, streamflow, and lake-level monitoring and forecast. Farmers use this information in conjunction with attention to local sociopolitics and related changes in $\mathrm{Bi}$ ological Opinions, water rights, and management to anticipate, to the degree possible, the amount of water likely to be allocated and the potential for curtailment, both in an effort to minimize risk. With little exception, farmers report not using additional climate information, such as seasonal climate and drought outlooks, in the absence of a clear application for these where drought is both hydrological and regulatory.

During the last years of more pervasive drought, not only within the basin but in several western states, government agencies have enacted the curtailment of water for agriculture (Fagundes 2015; Goth 2014; Lund et al. 2014). If regulatory drought continues under the warmer and drier conditions predicted for much of the region in the future (Cook et al. 2015; Miller et al. 2016), the influence both of biophysical and of sociopolitical factors on the availability and distribution of scarce water resources implies added complexity for the production of useful climate information. Certainly farmer use of snowpack, streamflow, and lake-level data in this study suggests that not all climate or climate-related information need be coproduced. We suggest, however, that as researchers continue to develop such information for agriculture, a coproduction approach will aid in uncovering the nuance of these increasingly complex decision-making contexts, here demonstrated as essential for understanding what information will be of use.

Acknowledgments. We thank the representatives of Klamath Basin agriculture who participated in the research as well as the editors and two anonymous reviewers for their valuable insights and feedback. NOAA's California-Nevada Climate Applications Program award NA11OAR4310150 supported the project.

\section{REFERENCES}

Artikov, I., and Coauthors, 2006: Understanding the influence of climate forecasts on farmer decisions as planned behavior. J. Appl. Meteor. Climatol., 45, 1202-1214, https://doi.org/ 10.1175/JAM2415.1.

Ash, A., P. McIntosh, B. Cullen, P. Carberry, and M. S. Smith, 2007: Constraints and opportunities in applying seasonal climate forecasts in agriculture. Crop Pasture Sci., 58, 952-965, https://doi.org/10.1071/AR06188.

Asseng, S., P. C. McIntosh, G. Wang, and N. Khimashia, 2012: Optimal $\mathrm{N}$ fertiliser management based on a seasonal forecast. Eur. J. Agron., 38, 66-73, https://doi.org/10.1016/ j.eja.2011.12.005.

Bartels, W.-L., and Coauthors, 2013: Warming up to climate change: a participatory approach to engaging with agricultural stakeholders in the Southeast US. Reg. Environ. Change, $\mathbf{1 3}$ (Suppl. 1) 45-55, https://doi.org/10.1007/s10113-012-0371-9.

Bernard, R. H., 2006: Research Methods in Anthropology: Qualitative and Quantitative Approaches. 4th ed. AltaMira Press, $824 \mathrm{pp}$.

Breuer, N. E., V. E. Cabrera, K. T. Ingram, K. Broad, and P. E. Hildebrand, 2008: AgClimate: A case study in participatory decision support system development. Climatic Change, 87, 385-403, https://doi.org/10.1007/s10584-007-9323-7.

_ C. W. Fraisse, and P. E. Hildebrand, 2009: Molding the pipeline into a loop: the participatory process of developing AgroClimate, a decision support system for climate risk reduction in agriculture. J. Service Climatol., 3, 1-12, https:// www.stateclimate.org/journalofserviceclimatology/articles/ vol2009no5.

Cabrera, V. E., N. E. Breuer, and P. E. Hildebrand, 2006: North Florida dairy farmer perceptions toward the use of seasonal climate forecast technology. Climatic Change, 78, 479-491, https://doi.org/10.1007/s10584-006-9053-2.

, D. Letson, and G. Podestá, 2007: The value of climate information when farm programs matter. Agric. Syst., 93, 25-42, https://doi.org/10.1016/j.agsy.2006.04.005.

Cook, B. I., T. R. Ault, and J. E. Smerdon, 2015: Unprecedented 21st century drought risk in the American Southwest and Central Plains. Sci. Adv., 1, e1400082, https://doi.org/10.1126/ sciadv.1400082.

Crane, T. A., C. Roncoli, J. Paz, N. E. Breuer, K. Broad, K. T. Ingram, and G. Hoogenboom, 2008a: Seasonal Climate Forecasts and Risk Management among Georgia Farmers. Southeast Climate Consortium Technical Rep. 08-003, 34 pp.

_ velopment of climate-based decision support systems: What role for social sciences? Third Symp. on Policy and Socio-Economic Research, New Orleans, LA, Amer. Meteor. Soc., 1.6, https://ams.confex.com/ams/88Annual/webprogram/ Paper135150.html.

, C. Roncoli, J. Paz, N. Breuer, K. Broad, K.T. Ingram, and G. Hoogenboom, 2010: Forecast skill and farmers' skills: Seasonal climate forecasts and agricultural risk management in the southeastern United States. Wea. Climate Soc., 2, 44-59, https://doi.org/10.1175/2009WCAS1006.1.

Dalton, M. M., P. W. Mote, and A. K. Snover, Eds., 2013: Climate Change in the Northwest: Implications for Our Landscapes, Waters, and Communities. Island Press, $270 \mathrm{pp}$.

Doremus, H. D., and A. D. Tarlock, 2008: Water War in the Klamath Basin: Macho Law, Combat Biology, and Dirty Politics. Island Press, $280 \mathrm{pp}$. 
Fagundes, J., 2015: Water curtailment limits farmers in Mason and Smith Valley. Nevada Farm Bureau Federation: Nevada Agriculture News, http://nvfb.org/2015/03/09/water-curtailment-limits-farmersin-mason-and-smith-valley/.

Fraisse, C. W., and Coauthors, 2006: AgClimate: A climate forecast information system for agricultural risk management in the southeastern USA. Comput. Electron. Agric., 53, 13-27, https://doi.org/10.1016/j.compag.2006.03.002.

Furman, C., C. Roncoli, T. Crane, and G. Hoogenboom, 2011: Beyond the "fit": Introducing climate forecasts among organic farmers in Georgia (United States). Climatic Change, 109, 791-799, https://doi.org/10.1007/s10584-011-0238-y.

Gershunov, A., and Coauthors, 2013: Future climate: Projected extremes. Assessment of Climate Change in the Southwest United States: A Report Prepared for the National Climate Assessment, G. Garfin et al., Eds., Island Press, 126-147.

Goth, B., 2014: Arizona farmers take hit to stave off water crisis. The Arizona Republic, 12 December 2014, http:// www.azcentral.com/story/news/local/arizona/2014/12/13/ ariz-farmers-take-hit-stave-water-crisis/20346417/.

Haigh, T., L. W. Morton, M. C. Lemos, C. Knutson, L. S. Prokopy, Y. J. Lo, and J. Angel, 2015a: Agricultural advisors as climate information intermediaries: Exploring differences in capacity to communicate climate. Wea. Climate Soc., 7, 83-93, https:// doi.org/10.1175/WCAS-D-14-00015.1.

, E. Takle, J. Andresen, M. Widhalm, S. J. Carlton, and J. Angel, 2015b: Mapping the decision points and climate information use of agricultural producers across the U.S. Corn Belt. Climate Risk Manage., 7, 20-30, https://doi.org/10.1016/ j.crm.2015.01.004.

Hollinger, S. E., 2009: Meteorological forecasting for agricultural production. Systems Analysis and Modeling in Food and Agriculture, K. C. Ting, D. H. Fleisher, and L. F. Rodriguez, Eds., EOLSS Publishers, 396-408.

Horangic, A., K. A. Berry, and T. Wall, 2016: Influences on stakeholder participation in water negotiations: A case study from the Klamath Basin. Soc. Nat. Resour., 29, 1421-1435, https://doi.org/10.1080/08941920.2016.1144837.

Jagtap, S., J. W. Jones, P. Hildebrand, D. Letson, J. J. O'Brien, G. Podestá, D. Zierden, and F. Zazueta, 2002: Responding to stakeholder's demands for climate information: From research to applications in Florida. Agric. Syst., 74, 415-430, https://doi.org/10.1016/S0308-521X(02)00048-3.

Klopper, E., C. H. Vogel, and W. A. Landman, 2006: Seasonal climate forecasts-Potential agricultural-risk management tools? Climatic Change, 76, 73-90, https://doi.org/10.1007/ s10584-005-9019-9.
Lund, J., B. Lord, W. Fleenor, and A. Willis, 2014: Drought curtailment of water rights-Problems and technical solutions. Center for Watershed Sciences, UC Davis. Technical comments to the State Water Resources Control Board, 23 pp., https://watershed.ucdavis.edu/ files/biblio/Water_right_curtailment_technical_ideas.pdf.

Mase, A. S., and L. S. Prokopy, 2014: Unrealized potential: A review of perceptions and use of weather and climate information in agricultural decision making. Wea. Climate Soc., 6, 47-61, https://doi.org/10.1175/WCAS-D-12-00062.1.

McCrea, R., L. Dalgleish, and W. Coventry, 2005: Encouraging use of seasonal climate forecasts by farmers. Int. J. Climatol., 25, 1127-1137, https://doi.org/10.1002/joc.1164.

Meinke, H., and R. C. Stone, 2005: Seasonal and inter-annual climate forecasting: The new tool for increasing preparedness to climate variability and change in agricultural planning and operations. Climatic Change, 70, 221-253, https://doi.org/ 10.1007/s10584-005-5948-6.

Miller, K. A., A. F. Hamlet, and D. S. Kenney, 2016: Introduction: The context for western water policy and planning. Water Policy and Planning in a Variable and Changing Climate: Insights from the Western United States, K. A. Miller et al., Eds., Taylor \& Francis, 3-16.

National Marine Fisheries Service and U.S. Fish and Wildlife Service, 2013: Biological Opinions on the effects of proposed Klamath Project operations from May 31, 2013, through March 31, 2023, on five federally listed threatened and endangered species. National Marine Fisheries Service and U.S. Fish and Wildlife Service, 590 pp., https://www.fws. gov/klamathfallsfwo/news/2013\%20BO/2013-Final-KlamathProject-BO.pdf.

Phillips, J., D. Deane, L. Unganai, and A. Chimeli, 2002: Implications of farm-level response to seasonal climate forecasts for aggregate grain production in Zimbabwe. Agric. Syst., 74, 351-369, https:// doi.org/10.1016/S0308-521X(02)00045-8.

Powers, K., P. Baldwin, E. H. Buck, and B. A. Cody, 2005: Klamath River basin issues and activities: An overview. Congressional Research Service, 39 pp., www.energy.ca.gov/hydroelectric/ klamath/documents/CRS_REPORT_RL33098.PDF.

Prokopy, L. S., J. S. Carlton, T. Haigh, M. C. Lemos, A. S. Mase, and M. Widhalm, 2017: Useful to usable: Developing usable climate science for agriculture. Climate Risk Manage., 15, 1-7, https://doi.org/10.1016/j.crm.2016.10.004.

Roudier, P., B. Muller, P. d'Aquino, C. Roncoli, M. A. Soumaré, L. Batté, and B. Sultan, 2014: The role of climate forecasts in smallholder agriculture: Lessons from participatory research in two communities in Senegal. Climate Risk Manage., 2, 42-55, https://doi.org/10.1016/j.crm.2014.02.001. 